\title{
Effects of Zinc Application on Some Important Yield and Quality Characteristics of Coriander (Coriandrum sativum L.)
}

\author{
Doğan Güneş ÖZBEK ${ }^{1}$, Erman BEYZİं ${ }^{*}$
}

\begin{abstract}
In this study, the effects of zinc application on the yield and quality characteristics of coriander were investigated. The experiments were conducted in randomized blocks split plots experimental design with 4 replications. In the experiment, coriander cultivars (Arslan and Gürbüz) were placed in the main plots and zinc doses (Control, 200, 400, $800 \mathrm{~g} \mathrm{da}^{-1}$ ) were placed in the subplots. In the study, cultivar $\mathrm{x}$ zinc interaction was significant in the number of umbels per plant and essential oil content; zinc treatments were found to be significant in the number of branches per plant, biological and fruit yield, essential and crude oil contents; cultivars were significant in thousand fruit weight and harvest index. In this study, fruit yield varied between $120-185 \mathrm{~kg} \mathrm{da}^{-1}$, essential oil content varied between 0.40-0.55\% and crude oil content varied between 10.8-14.6\%. In essential oil composition analysis, linalool was the main component, while in fatty acid composition analysis petroselinic acid was determined as the main component. At the end of the study, it was determined that $800 \mathrm{~g} \mathrm{da}^{-1} \mathrm{zinc}$ dose of Arslan cultivar was appropriate in terms of fruit yield. Also, the $200 \mathrm{~g} \mathrm{da}^{-1} \mathrm{zinc}$ dose of Gürbüz cultivar and the $800 \mathrm{~g} \mathrm{da}^{-1}$ zinc dose of Arslan cultivar had the highest values in terms of linalool and petroselinic acid ratios respectively.
\end{abstract}

Keywords: Coriander, zinc, fruit yield, fatty acid composition, essential oil composition

\section{Çinko Uygulamasının Kişnişin (Coriandrum sativum L.) Bazı Önemli Verim ve Kalite Özelliklerine Etkileri}

\section{öz}

$\mathrm{Bu}$ çalışmada, çinko uygulamasının kişniş bitkisinin verim ve kalite özelliklerine etkisi araştırılmıştır. Deneme, tesadüf blokları bölünmüş parseller deneme desenine göre 4 tekerrürlü olarak yürütülmüştür. Denemede kişniş çeşitleri (Arslan ve Gürbüz) ana parsellere, çinko dozları (Kontrol, 200, 400, $800 \mathrm{~g} \mathrm{da}^{-1}$ ) ise alt parsellere yerleştirilmiştir. Araştırmada çeşit x çinko interaksiyonu bakımından bitki başına düşen şemsiye sayısı ve uçucu yağ oranlarının; çinko uygulamaları bakımıdan bitki başına dal sayısı, biyolojik ve meyve verimi, uçucu ve ham yağ oranlarının ve çeşitler bakımından ise bin meyve ağırlığı 1 ve hasat indeksinin istatistiki olarak önemli olduğu bulunmuştur. Bu çalışmada meyve verimi $120-185 \mathrm{~kg} \mathrm{da}^{-1}$, uçucu yağ içeriği \% 0.40-0.55 arasında, sabit yağ içeriği ise \% 10.8-14.6 arasında değişmiştir. Uçucu yağ bileşenleri analizinde ana bileşen linalol, yağ asidi kompozsiyonu analizinde ise ana bileşen petroselinik asit olarak ortaya çıkmıştır. Araştırma sonucunda Arslan çeşidinin $800 \mathrm{~g} \mathrm{da}^{-1}$ çinko dozunun meyve verimi açısından uygun olduğu belirlenmiştir. Ayrıca linalool oranı için Gürbüz çeşidinde $200 \mathrm{~g} \mathrm{da}^{-1}$ çinko dozu ve petroselinik asit oranı için ise Arslan çeşidinde $800 \mathrm{~g} \mathrm{da}^{-1}$ çinko dozu en yüksek değerlere sahip olmuştur.

Anahtar kelimeler: Kişniş, çinko, meyve verimi, yağ asidi komposiyonu, uçucu yağ bileşenleri

ORCID ID (Yazar sirasına göre)

0000-0002-4380-7192, 0000-0002-0248-4227

Yayın Kuruluna Geliş Tarihi: 30.09.2021

Kabul Tarihi: 28.12.2021

${ }^{1}$ Erciyes University, Faculty of Agriculture, Department of Field Crops, 38039, Kayseri, Turkey

*E-posta: ermanbeyzi@gmail.com 


\section{Effects of Zinc Application on Some Important Yield and Quality Characteristics of Coriander (Coriandrum sativum L.)}

\section{Introduction}

Coriander (Coriandrum sativum L.) is a spice plant known by names such as 'Kișniș, Așotu, Kuzbere'" in Turkey (Baytop, 1984). In addition, this plant is a valuable and annual plant with white flowers (Ghasemi Pirbalouti et al., 2017). It comes from the Mediterranean countries and is now grown mostly in Morocco, Italy, India, Eastern European countries (Ramadan and Mörsel, 2002).

Coriander is a herbaceous plant belonging to Umbelliferae family and contains antibacterial, antifungal and antioxidant activities (Mandal and Mandal, 2015). Both the green leaves and fruits of the plant are used (Tunçtürk, 2011) and they are generally produced for their fruits (Zoubiri and Baaliouamer, 2010). Herbal parts of coriander are evaluated as a flavoring agent in food products, perfumes and cosmetic products and have economic value (Msaada et al., 2007). In addition, this plant has been used in folk medicine for many years due to its digestive carminative and appetizing properties (Tunçtürk, 2011).

Coriander fruits contain essential oil content between 0.3-1.2\% (Khodadadi et al., 2016), crude oil content between 17.80-19.15\% (Ulutaş Deniz et al., 2018), crude protein content between 11.5-21.3\%, crude fiber between 28.4$29.1 \%$ and crude ash between $4.9-6.0 \%$ (Ulutaş Deniz et al., 2018). Its essential oil is rich in terms of linalool content and its crude oil is rich in terms of petroselinic acid (C18: $1 \mathrm{n} 12)$ content (Sriti et al., 2012). Linalool content in essential oil is between $60-70 \%$ (Khodadadi et al., 2016), and petroselinic acid content in crude oil is between 55-80\% (Kaya et al., 2000).

Zinc is a micronutrient element and important for both humans and plants. Zinc element has important roles in growth and development, reproductive health and immune system. It also plays a role in protein, fat metabolism and DNA replication (Deshpande et al., 2017;

Maret, 2013). In this study, the effects of zinc application on the yield and quality characteristics of coriander were investigated.

\section{Material and methods} Material and chemicals
Arslan and Gürbüz coriander cultivars registered in Ankara University Faculty of Agriculture, Department of Field Crops were used as plant material in this study. In addition, the zinc fertilizer used in the study (water-soluble zinc $13 \%$, zinc chelated with ETA $10.4 \%$ and $\mathrm{pH}$ range of stable EDTA chelate: 3-7 for zinc) was obtained from Doğatech company. Standards (Sigma-Aldrich, Milan, Italy) for the determination of fatty acid composition and $\alpha$ pinene, myrcene, limonene, $\gamma$-terpinene, camphor, linalool, terpinen-4-ol, $\alpha$-terpineol, geranyl acetate and geraniol standards for the determination of essential oil composition (Sigma-Aldrich, Milan, Italy) were used in this study.

\section{Establishing the experiment}

This study was carried out in Erciyes University Agricultural Research and Application Center experimental fields as a summer season in the 2019 year. Experiments were conducted in randomized blocks split plots experimental design with 4 replications. In the experiment, coriander cultivars (Arslan and Gürbüz) were placed in the main plots and zinc treatments (Control, 200, 400 and $800 \mathrm{~g} \mathrm{da}^{-1}$ ) were placed in the subplots. In the study, sowing was done on 20 March 2019 with six rows and with $40 \mathrm{~cm}$ inter row space per parcel. The meteorological data and soil characteristics of the experimental field were given in Table 1 .

\section{Zinc application and harvesting processes}

Foliar zinc application was applied in two parts in selected doses and one half of doses was used at plants reached to $10 \mathrm{~cm}$ height. Accordingly, the first application was made on 8 May 2019 and the second application on 15 May 2019. In the experimental area, base fertilization $(50 \mathrm{~kg}$ of nitrogen and $50 \mathrm{~kg}$ of phosphorus per hectare as pure), weed control and plant irrigation were performed. The harvest was made by hand on 16 July 2019. In the harvest, first and last rows in each parcel were left as edge effects. The measurements, weighing and calculations were made in the middle four rows after the edge effects were removed. 


\section{Effects of Zinc Application on Some Important Yield and Quality Characteristics of Coriander (Coriandrum sativum L.)}

Table 1. Meteorological data and soil properties of experimental field

\begin{tabular}{lccc}
\hline Meteorological data & \multicolumn{3}{c}{ average } \\
\hline Months & $\begin{array}{c}\text { average relative } \\
\text { temperature } \\
\left({ }^{\circ} \mathbf{C}\right)\end{array}$ & $\begin{array}{c}\text { total } \\
\text { humidity } \\
(\%)\end{array}$ & $\begin{array}{c}\text { precipitation } \\
(\mathbf{m m})\end{array}$ \\
\hline March & 5.6 & 59.3 & 29.3 \\
April & 9.2 & 66.4 & 41.1 \\
May & 17.4 & 50.2 & 25.7 \\
June & 21.3 & 55.8 & 54.0 \\
July & 21.6 & 49.1 & 35.3 \\
\hline Soil properties & & & \\
\hline pH & & 7.62 & \\
EC (mmhos $\left.\mathrm{cm}^{-1}\right)$ & & 0.06 & \\
Lime $(\%)$ & & 3.15 & \\
Organic matter $(\%)$ & & 1.25 & \\
Phosphorus $\left(\mathrm{kg} \mathrm{da}^{-1}\right)$ & & 1.60 & \\
Texture & & Loam & \\
\hline
\end{tabular}

After harvest, measurements of plant height, first branch height, the number of branches per plant, the number of umbels per plant, the number of fruits per umbel were made on ten plants randomly selected from each plot. For thousand fruit weight, 4 x 100 fruit groups from each plot were counted and weight, then the average of the weights was multiplied by ten. Biological yield was found by weighing all the plants harvested in each plot. Fruit yield was found by weighing the harvested fruits. While calculating the essential oil content, the fruits $(100 \mathrm{~g})$ from each plot were distilled ( 3 hours and in $1 \mathrm{~L}$ water) using the Clevenger apparatus. The essential oil content was given in dry matter and in $\%$. While determining the crude oil content, the fruits obtained from each plot $(4 \mathrm{~g})$ were analysed with petroleum ether in the oil analyser according to the Soxhlet method. The crude oil content was given in dry matter and in \%. Essential oil compositions were determined in $\%$ by comparison with standards in gas chromatography device (Schimadzu, GC 2010 plus). Fatty acid compositions were determined using gas chromatography device (Schimadzu, GC 2010 plus), flame ionization detector (FID) and column (60 m, $0.53 \mathrm{~mm}$, RTX-200). The standards containing fatty acids were used to determine the fatty acid compositions. Fatty acid compositions were given in $\%$.

Statistical analysis
Data obtained on yield and yield components were subjected to variance analysis in the MSTAT-C package program and Duncan's multiple range test was applied to determine the significance levels of the differences between applications. The significance of the differences obtained in terms of cultivars was determined by t-test (Düzgüneş et al., 1987).

\section{Results and Discussion \\ Yield and yield components}

According to coriander cultivars and zinc treatments, plant height varied between 54.8$64.3 \mathrm{~cm}$, first branch height varied between 32.3$37.2 \mathrm{~cm}$, the number of branches per plant varied between 3.15-4.15, the number of umbels per plant varied between $4.95-8.00$, the number of fruits per umbel varied between 12.6-17.6, thousand fruit weight varied between 9.47-12.37 $\mathrm{g}$, biological yield varied between $524-781 \mathrm{~kg}$ $\mathrm{da}^{-1}$, fruit yield varied between 120-185 $\mathrm{kg} \mathrm{da}^{-1}$, harvest index varied between 19.2-26.0\%, essential oil content varied between $0.40-0.55 \%$, and crude oil content varied between 10.8$14.6 \%$. In the analysis of variance, cultivar $\mathrm{x}$ zinc interaction was found to be significant in the number of umbels per plant $(p<0.05)$ and essential oil content $(p<0.01)$. The highest number of umbels per plant was obtained from the $800 \mathrm{~g} \mathrm{da}^{-1}$ zinc treatment in Arslan cultivar and the lowest was obtained from the $800 \mathrm{~g} \mathrm{da}^{-1}$ zinc treatment in Gürbüz cultivar. The highest and lowest essential oil contents were obtained 


\section{Effects of Zinc Application on Some Important Yield and Quality Characteristics of Coriander (Coriandrum sativum L.)}

from $400 \mathrm{~g} \mathrm{da}^{-1}$ and $200 \mathrm{~g} \mathrm{da}^{-1}$ zinc treatments in the Arslan cultivar, respectively (Table 2).

Variance analysis revealed that zinc treatment was significant for the number of branches per plant $(\mathrm{p}<0.05)$, biological yield $(\mathrm{p}<0.05)$, fruit yield $(p<0.05)$, essential oil content $(p<0.01)$ and crude oil content $(\mathrm{p}<0.01)$; was not significant for plant height, first branch height, the number of umbels per plant, the number of fruits per umbel, thousand fruit weight and harvest index. The cultivars were significant for thousand fruit weight $(p<0.01)$ and harvest index $(p<0.01)$. In zinc treatment averages, the highest number of branches per plant (4.03), biological yield (753 $\left.\mathrm{kg} \mathrm{da}^{-1}\right)$ and fruit yield $\left(168 \mathrm{~kg} \mathrm{da}^{-1}\right)$ were obtained from $800 \mathrm{~g} \mathrm{da}^{-1}$ zinc treatment. The highest essential oil content $(0.52 \%)$ obtained from $400 \mathrm{~g} \mathrm{da}^{-1}$ zinc treatment and, the highest crude oil content (14.6\%) obtained from the parcels without zinc. In cultivars averages, the highest thousand fruit weight $(11.70 \mathrm{~g})$ and harvest index $(24.0 \%)$ were obtained from Arslan cultivar (Table 2).

In previous studies about coriander plant; Kan (2007) reported plant height as between 46.7$49.7 \mathrm{~cm}$; Katar (2015) as $53.5 \mathrm{~cm}$ in Gürbüz cultivar, as $48.8 \mathrm{~cm}$ in Arslan cultivar; Kaya et al. (2000) as between $34.2-74.0 \mathrm{~cm}$ in the first year (2017), as between $40.0-82.0 \mathrm{~cm}$ in the second year (2018). Beyzi et al. (2017a) reported first branch height as between $5.48-6.10 \mathrm{~cm}$ in Arslan cultivar and as between $6.23-6.90 \mathrm{~cm}$ in Gürbüz cultivar; Erdoğdu (2012) as between $6.50-13.70 \mathrm{~cm}$. Kan (2007) reported the number of branches per plant as between 4.33-4.39; Kaya et al. (2000) as between 3.7-6.1 in the first year (2017) and as between 3.7-7.7 in the second year (2018).

Katar (2015) reported the number of umbels per plant as between 7.07-13.00; Tunçtürk (2006) as between 15.35-16.86. Tunçtürk (2006) reported the number of fruits per umbel as between 21.728.0 in the first year and as between 22.1-32.0 in the second year; K1z1l and İpek (2004) as between 34.1-39.4. Kan (2007) reported thousand fruit weight as between 9.17-10.55 g; Kiz1l and İpek (2004) as between 13.02-13.16 g; Tunçtürk (2006) as between 10.73-11.86 g.

Gökduman and Telci (2018) reported biological yield as between 184-450 kg da-1; Gücük (2014) as between $690-860 \mathrm{~kg} \mathrm{da}^{-1}$. Kan (2007) reported fruit yield as between 53.2-59.1 kg da'; Gökduman and Telci (2018) as between 48-113 $\mathrm{kg} \mathrm{da}^{-1}$; K1z1l and İpek (2004) as between 98.5$181 \mathrm{~kg} \mathrm{da}^{-1}$; Tunçtürk (2006) as between 93.6$126 \mathrm{~kg} \mathrm{da}^{-1}$. Beyzi et al. (2017a) reported harvest index as between 28.9-39.3\% in Arslan cultivar and as between 22.0-35.9\% in Gürbüz cultivar; Erdoğdu (2012) as between 23.50-39.10\%.

Kan (2007) reported essential oil content as between 0.21-0.22\%; Beyzi and Gürbüz (2014) as between $0.23-0.34 \%$. Beyzi et al. (2017a) reported crude oil content as between 6.47$7.45 \%$ in Arslan cultivar and as between 5.23$6.75 \%$ in Gürbüz cultivar.

\section{Essential oil and fatty acid compositions}

According to coriander cultivars and different zinc treatments, 10 essential oil components were examined in the fruit. The major component was linalool and followed by geraniol and camphor respectively. 
Effects of Zinc Application on Some Important Yield and Quality Characteristics of Coriander (Coriandrum sativum L.)

Table 2. Changes in some yield and quality characteristics of coriander cultivars according to zinc treatment

\begin{tabular}{|c|c|c|c|c|c|c|c|c|c|c|c|c|}
\hline \multicolumn{2}{|c|}{ Applications } & PH & FBH & NB & $\mathbf{N U}$ & NF & TFW & BY & SY & HI & EO & $\mathrm{CO}$ \\
\hline \multirow[t]{4}{*}{ Arslan } & 0 & 56.3 & 32.3 & 3.15 & $6.70^{\mathrm{AB}}$ & 16.4 & 11.61 & 524 & 120 & 22.9 & $0.45^{\mathrm{bc}}$ & 14.6 \\
\hline & $200 \mathrm{~g} \mathrm{da}^{-1}$ & 56.0 & 36.0 & 3.25 & $5.33^{\mathrm{BC}}$ & 12.6 & 12.37 & 719 & 152 & 21.6 & $0.40^{\mathrm{c}}$ & 13.9 \\
\hline & $400 \mathrm{~g} \mathrm{da}^{-1}$ & 59.3 & 36.2 & 3.85 & $6.20^{\mathrm{BC}}$ & 15.1 & 11.72 & 596 & 154 & 26.0 & $0.55^{\mathrm{a}}$ & 13.1 \\
\hline & $800 \mathrm{~g} \mathrm{da}^{-1}$ & 64.3 & 34.8 & 4.13 & $8.00^{\mathrm{A}}$ & 17.6 & 11.11 & 726 & 185 & 25.5 & $0.51^{\mathrm{ab}}$ & 12.7 \\
\hline \multirow[t]{4}{*}{ Gürbüz } & 0 & 56.2 & 33.6 & 3.78 & $5.13^{\mathrm{C}}$ & 15.3 & 9.51 & 631 & 121 & 19.2 & $0.53^{\mathrm{a}}$ & 14.6 \\
\hline & $200 \mathrm{~g} \mathrm{da}^{-1}$ & 61.7 & 37.2 & 4.15 & $5.63^{\mathrm{BC}}$ & 13.5 & 9.76 & 684 & 142 & 20.7 & $0.51^{\mathrm{ab}}$ & 13.4 \\
\hline & $400 \mathrm{~g} \mathrm{da}^{-1}$ & 58.5 & 34.3 & 4.10 & $5.35^{\mathrm{BC}}$ & 15.3 & 9.47 & 635 & 121 & 19.2 & $0.49^{\mathrm{ab}}$ & 12.6 \\
\hline & $800 \mathrm{~g} \mathrm{da}^{-1}$ & 54.8 & 33.9 & 3.93 & $4.95^{\mathrm{C}}$ & 13.5 & 9.79 & 781 & 152 & 19.6 & $0.49^{a b}$ & 10.8 \\
\hline \multicolumn{2}{|l|}{ Mean } & 58.4 & 34.8 & 3.79 & 5.91 & 14.9 & 10.67 & 662 & 143.4 & 21.8 & 0.49 & 13.2 \\
\hline \multicolumn{2}{|l|}{ Arslan } & 59.0 & 34.8 & 3.59 & 6.56 & 15.4 & $11.70^{\mathrm{a}}$ & 641 & 153 & $24.0^{\mathrm{a}}$ & 0.48 & 13.6 \\
\hline \multicolumn{2}{|l|}{ Gürbüz } & 57.8 & 34.8 & 3.99 & 5.26 & 14.4 & $9.63^{b}$ & 683 & 134 & $19.7^{\mathrm{b}}$ & 0.50 & 12.8 \\
\hline \multicolumn{2}{|c|}{0} & 56.3 & 33.0 & $3.46^{\mathrm{B}}$ & 5.91 & 15.9 & 10.56 & $578^{\mathrm{C}}$ & $121^{\mathrm{B}}$ & 21.0 & $0.49^{\mathrm{ab}}$ & $14.6^{\mathrm{a}}$ \\
\hline \multicolumn{2}{|c|}{$200 \mathrm{~g} \mathrm{da}^{-1}$} & 58.8 & 36.6 & $3.70 \mathrm{AB}$ & 5.48 & 13.1 & 11.06 & $702^{\mathrm{AB}}$ & $147 \mathrm{AB}$ & 21.1 & $0.45^{\mathrm{b}}$ & $13.6^{\mathrm{ab}}$ \\
\hline \multicolumn{2}{|c|}{$400 \mathrm{~g} \mathrm{da}^{-1}$} & 58.9 & 35.3 & $3.98^{\mathrm{A}}$ & 5.78 & 15.2 & 10.59 & $615^{\mathrm{BC}}$ & $138^{\mathrm{B}}$ & 22.6 & $0.52^{\mathrm{a}}$ & $12.9^{b c}$ \\
\hline \multicolumn{2}{|c|}{$800 \mathrm{~g} \mathrm{da}^{-1}$} & 59.6 & 34.4 & $4.03^{\mathrm{A}}$ & 6.48 & 15.5 & 10.45 & $753^{A}$ & $168^{\mathrm{A}}$ & 22.5 & $0.50^{a b}$ & $11.7^{\mathrm{c}}$ \\
\hline
\end{tabular}

PH: plant height; FBH: first branch height, NB: number of branches; NU: number of umbels per plant; NF: number of fruits per umbel; TFW: thousand fruit weight; BY: biological yield; FY: fruit yield; HI: harvest index; EO: essential oil content; CO: crude oil content; capital letters show different groups at $5 \%$ level; small letters show different groups at $1 \%$ level 


\section{Effects of Zinc Application on Some Important Yield and Quality Characteristics of Coriander (Coriandrum sativum L.)}

Linalool content varied between 82.9-86.6\%. The highest linalool content was obtained from $200 \mathrm{~g} \mathrm{da}^{-1}$ zinc treatment in Gürbüz cultivar and the lowest was obtained from the $800 \mathrm{~g} \mathrm{da}^{-1}$ zinc treatment in Arslan cultivar. Geraniol content varied between 2.85-3.67\%. The highest geraniol content was obtained from $400 \mathrm{~g} \mathrm{da}^{-1}$ zinc treatment in Arslan cultivar and the lowest was obtained from the $200 \mathrm{~g} \mathrm{da}^{-1}$ zinc treatment in Gürbüz cultivar. Camphor content varied between $0.17-3.06 \%$. The highest camphor content was obtained from $800 \mathrm{~g} \mathrm{da}^{-1}$ zinc treatment in Arslan cultivar and the lowest was obtained from control plots without zinc in Arslan cultivar. $\alpha$-pinene content varied between $0.23-0.82 \%$, myrcene content varied between $0.09-0.21 \%$, limonene content varied between $0.27-0.53 \%, \gamma$-terpinene content varied between $1.60-2.94 \%$, terpinen-4-ol content varied between $0.17-0.21 \%, \alpha$ - terpineol content varied between $0.28-0.33 \%$, and geranyl acetate content varied between 1.53-2.78\% (Table 3).

In previous studies about coriander plant; Beyzi and Güneş (2017) reported linalool content as between 83.8-91.4\%; Özel et al. (2010) as between $69.5-85.6 \%$ in the first year and as between $75.8-82.8 \%$ in the second year, Beyzi and Güneş (2017) reported geraniol content as between 1.67-3.16\%; Özel et al. (2010) 0.14$0.30 \%$ in the first year and as between 0.15 $0.46 \%$ in the second year, Beyzi and Güneş (2017) reported camphor content as between 2.21-3.67\%; Özel et al. (2010) 1.69-3.13\% in the first year and as between $2.56-3.44 \%$ in the second year.

In the study, 9 fatty acid composition were identified. The major component was petroselinic acid (C18:1 n12) and it was respectively followed by linoleic acid (C18:2) and oleic acid (C18:1 n9). Petroselinic acid (C18:1 n12) content varied between 72.2-79.6\%. The highest petroselinic acid content was obtained from $800 \mathrm{~g} \mathrm{da}^{-1}$ zinc treatment in Arslan cultivar and the lowest was obtained from control plots without zinc in Arslan cultivar. Linoleic acid (C18:2) content varied between 11.6-13.8\%. The highest linoleic acid content was obtained from control plots without zinc in Arslan cultivar and the lowest was obtained from $400 \mathrm{~g} \mathrm{da}^{-1}$ zinc treatment in Arslan cultivar. Oleic acid (C18:1 n9) content varied between $3.50-6.71 \%$. The highest oleic acid content was obtained from $200 \mathrm{~g} \mathrm{da}^{-1}$ zinc treatment in Arslan cultivar and the lowest was obtained from $800 \mathrm{~g}$ $\mathrm{da}^{-1}$ zinc treatment in Arslan cultivar. Palmitic acid (C16:0) content varied between 3.05$5.48 \%$, palmitoleic acid (C16:1) content varied between $0.19-1.13 \%$, stearic acid (C18:0) content varied between $0.72-1.77 \%$, linolenic acid (C18:3) content varied between 0.16$0.69 \%$, arachidic acid (C20:0) content varied between $0.10-0.56 \%$, and eicosenoic acid (C20:1) content varied between 0.21-0.47\% (Table 4).

In previous studies about coriander plant; Keskin (2015) reported petrosenilic acid content as 79.6\%; Beyzi et al. (2017b) as 79.8\% in Arslan cultivar and as $81.5 \%$ in Gürbüz cultivar, Keskin (2015) reported linoleic acid content as $13.7 \%$; Beyzi et al. (2017b) as $14.7 \%$ in Arslan cultivar and as $14.0 \%$ in Gürbüz cultivar, Keskin (2015) reported oleic acid content as $0.90 \%$ 
Effects of Zinc Application on Some Important Yield and Quality Characteristics of Coriander (Coriandrum sativum L.)

Table 3. Changes in essential oil compositions of coriander cultivars according to zinc treatment

\begin{tabular}{|c|c|c|c|c|c|c|c|c|c|c|c|}
\hline \multicolumn{2}{|c|}{ Applications } & AP & MY & LM & GT & CM & $\mathbf{L L}$ & $\mathbf{T P}$ & AT & GA & GR \\
\hline \multirow[t]{4}{*}{ Arslan } & 0 & 0.49 & 0.16 & 0.42 & 2.17 & 0.17 & 85.4 & 0.20 & 0.30 & 1.78 & 3.06 \\
\hline & $200 \mathrm{~g} \mathrm{da}^{-1}$ & 0.74 & 0.20 & 0.49 & 2.28 & 2.75 & 83.6 & 0.20 & 0.31 & 1.75 & 3.12 \\
\hline & $400 \mathrm{~g} \mathrm{da}^{-1}$ & 0.23 & 0.09 & 0.27 & 1.60 & 2.61 & 85.9 & 0.21 & 0.33 & 1.53 & 3.67 \\
\hline & $800 \mathrm{~g} \mathrm{da}^{-1}$ & 0.82 & 0.21 & 0.53 & 2.94 & 3.06 & 82.9 & 0.20 & 0.31 & 2.78 & 3.03 \\
\hline \multirow[t]{4}{*}{ Gürbüz } & 0 & 0.78 & 0.17 & 0.40 & 2.35 & 2.60 & 86.3 & 0.18 & 0.29 & 1.97 & 3.16 \\
\hline & $200 \mathrm{~g} \mathrm{da}^{-1}$ & 0.33 & 0.13 & 0.33 & 2.08 & 2.57 & 86.6 & 0.19 & 0.31 & 2.64 & 2.85 \\
\hline & $400 \mathrm{~g} \mathrm{da}^{-1}$ & 0.68 & 0.19 & 0.45 & 2.70 & 2.65 & 86.0 & 0.17 & 0.28 & 1.61 & 3.44 \\
\hline & $800 \mathrm{~g} \mathrm{da}^{-1}$ & 0.57 & 0.18 & 0.45 & 2.74 & 2.68 & 86.0 & 0.17 & 0.28 & 1.76 & 3.29 \\
\hline \multicolumn{2}{|l|}{ Mean } & 0.58 & 0.17 & 0.42 & 2.36 & 2.39 & 85.3 & 0.19 & 0.30 & 1.98 & 3.20 \\
\hline \multicolumn{2}{|l|}{ Arslan } & 0.57 & 0.17 & 0.43 & 2.25 & 2.15 & 84.4 & 0.20 & 0.31 & 1.96 & 3.22 \\
\hline \multicolumn{2}{|l|}{ Gürbüz } & 0.59 & 0.17 & 0.41 & 2.47 & 2.63 & 86.2 & 0.18 & 0.29 & 2.00 & 3.19 \\
\hline \multicolumn{2}{|c|}{0} & 0.64 & 0.17 & 0.41 & 2.26 & 1.39 & 85.8 & 0.19 & 0.30 & 1.88 & 3.11 \\
\hline \multicolumn{2}{|c|}{$200 \mathrm{~g} \mathrm{da}^{-1}$} & 0.54 & 0.17 & 0.41 & 2.18 & 2.66 & 85.1 & 0.20 & 0.31 & 2.20 & 2.99 \\
\hline \multicolumn{2}{|c|}{$400 \mathrm{~g} \mathrm{da}^{-1}$} & 0.46 & 0.14 & 0.36 & 2.15 & 2.63 & 86.0 & 0.19 & 0.31 & 1.57 & 3.56 \\
\hline \multicolumn{2}{|c|}{$800 \mathrm{~g} \mathrm{da}^{-1}$} & 0.70 & 0.20 & 0.49 & 2.84 & 2.87 & 84.5 & 0.19 & 0.30 & 2.27 & 3.16 \\
\hline
\end{tabular}

AP: $\alpha$-pinene; MY: myrcene; LM: limonene; GT: $\gamma$-terpinene; CM: camphor; LL: linalool; TP: terpinen-4-ol; AT: $\alpha$-terpineol; GA: geranyl acetate; GR: geraniol 
Effects of Zinc Application on Some Important Yield and Quality Characteristics of Coriander (Coriandrum sativum L.)

Table 4. Changes in fatty acid compositions of coriander cultivars according to zinc treatment

\begin{tabular}{|c|c|c|c|c|c|c|c|c|c|c|}
\hline \multicolumn{2}{|c|}{ Applications } & C16:0 & C16:1 & C18:0 & C18:1 n12 & C18:1 n9 & C18:2 & C18:3 & C20:0 & C20:1 \\
\hline \multirow[t]{4}{*}{ Arslan } & 0 & 4.83 & 0.38 & 1.36 & 72.2 & 5.90 & 13.8 & 0.69 & 0.56 & 0.30 \\
\hline & $200 \mathrm{~g} \mathrm{da}^{-1}$ & 4.86 & 0.28 & 1.44 & 73.5 & 6.71 & 12.3 & 0.36 & 0.29 & 0.27 \\
\hline & $400 \mathrm{~g} \mathrm{da}^{-1}$ & 3.09 & 0.19 & 0.75 & 78.4 & 5.36 & 11.6 & 0.20 & 0.21 & 0.27 \\
\hline & $800 \mathrm{~g} \mathrm{da}^{-1}$ & 3.05 & 0.20 & 0.85 & 79.6 & 3.50 & 12.4 & 0.16 & 0.14 & 0.21 \\
\hline \multirow[t]{4}{*}{ Gürbüz } & 0 & 3.21 & 0.44 & 0.72 & 78.6 & 3.72 & 12.5 & 0.27 & 0.18 & 0.32 \\
\hline & $200 \mathrm{~g} \mathrm{da}^{-1}$ & 3.98 & 1.13 & 0.72 & 77.4 & 3.53 & 12.3 & 0.20 & 0.21 & 0.47 \\
\hline & $400 \mathrm{~g} \mathrm{da}^{-1}$ & 3.54 & 0.69 & 0.89 & 77.9 & 3.91 & 12.6 & 0.16 & 0.10 & 0.23 \\
\hline & $800 \mathrm{~g} \mathrm{da}^{-1}$ & 5.48 & 0.64 & 1.77 & 75.5 & 3.92 & 11.8 & 0.20 & 0.20 & 0.42 \\
\hline \multicolumn{2}{|l|}{ Mean } & 4.01 & 0.49 & 1.06 & 76.6 & 4.57 & 12.4 & 0.28 & 0.24 & 0.31 \\
\hline \multicolumn{2}{|l|}{ Arslan } & 3.96 & 0.26 & 1.10 & 75.9 & 5.37 & 12.5 & 0.35 & 0.30 & 0.26 \\
\hline \multicolumn{2}{|l|}{ Gürbüz } & 4.05 & 0.73 & 1.03 & 77.4 & 3.77 & 12.3 & 0.21 & 0.17 & 0.36 \\
\hline \multicolumn{2}{|c|}{0} & 4.02 & 0.41 & 1.04 & 75.4 & 4.81 & 13.2 & 0.48 & 0.37 & 0.31 \\
\hline \multicolumn{2}{|c|}{$200 \mathrm{~g} \mathrm{da}^{-1}$} & 4.42 & 0.71 & 1.08 & 75.5 & 5.12 & 12.3 & 0.28 & 0.25 & 0.37 \\
\hline \multicolumn{2}{|c|}{$400 \mathrm{~g} \mathrm{da}^{-1}$} & 3.32 & 0.44 & 0.82 & 78.1 & 4.64 & 12.1 & 0.18 & 0.16 & 0.25 \\
\hline \multicolumn{2}{|c|}{$800 \mathrm{~g} \mathrm{da}^{-1}$} & 4.27 & 0.42 & 1.31 & 77.6 & 3.71 & 12.1 & 0.18 & 0.17 & 0.32 \\
\hline
\end{tabular}




\section{Effects of Zinc Application on Some Important Yield and Quality Characteristics of Coriander (Coriandrum sativum L.)}

\section{Conclusion}

In this study, the effects of zinc application on the yield and quality characteristics of coriander were investigated. In the study, cultivar $\mathrm{x}$ zinc interaction was significant in the number of umbels per plant and essential oil content; zinc treatments were found to be significant in the number of branches per plant, biological and fruit yield, essential and crude oil contents; cultivars were significant in thousand fruit weight and harvest index. At the end of the study, fruit yield varied between $120-185 \mathrm{~kg} \mathrm{da}$ 1 , essential oil content varied between 0.40$0.55 \%$, crude oil content varied between 10.8 $14.6 \%$. Linalool in essential oil component analysis and petroselinic acid in fatty acid composition analysis were determined as the main components. Linalool content varied between 82.9-86.6\% and petroselinic acid (C18: $1 \mathrm{n} 12)$ content varied between $72.2-79.6 \%$. The highest average values in linalool and petroselinic acid components were obtained from Gürbüz cultivar and $400 \mathrm{~g} \mathrm{da}^{-1}$ zinc treatment. At the end of the study, it was determined that $800 \mathrm{~kg} \mathrm{da}^{-1}$ zinc dose of Arslan cultivar was appropriate in terms of fruit yield. Also, the $200 \mathrm{~kg} \mathrm{da}^{-1}$ zinc dose of Gürbüz cultivar and the $800 \mathrm{~kg} \mathrm{da}^{-1}$ zinc dose of Arslan cultivar had the highest values in terms of linalool and petroselinic acid ratios respectively.

\section{Acknowledgements}

This study was produced from the Master Thesis of Doğan Güneş ÖZBEK. This study was supported by Scientific Research Projects Department of Erciyes University (with the project number of FYL-2018-8715). Authors express their sincere thanks to Scientific Research Projects Department of Erciyes University for the financial support provided for this project.

\section{References}

Baytop, T. (1984). Türkiye' de Bitkiler ile Tedavi. İstanbul Üniv. Yay. No;3255, Ecz. Fak. Yay. No: 40, İstanbul. (in Turkish)

Beyzi, E., Gurbuz, B. (2014). Effect of different fruit sizes on essential oil ratio and components of coriander. J. Essent. Oil Bear. Plant 17:1175-1180.

Beyzi, E., Güneş, A. (2017). The effects of boron application on essential oil components of coriander plant (Coriandrum sativum L.). J. Agric. Fac. Gaziosmanpasa Univ. 34:146-152.

Beyzi, E., Güneş, A., Gürbüz, B. (2017a). Effects of humic acid treatments of yield, morphological characteristics and essential oil components of coriander (Coriandrum sativum L.). Res. J. Soil Biol. 9:1-8.

Beyzi, E., Karaman, K., Güneş, A., Büyükkılıç Beyzi, S. (2017b). Change in some biochemical and bioactive properties and essential oil composition of coriander seed (Coriandrum sativum L.) varieties from Turkey. Ind. Crop. Prod. 109:74-78.

Düzgüneş, O., Kesici, T., Kavuncu, O., Gürbüz F. (1987). Araştırma ve Deneme Metotları (İstatistik Metotları II). Ankara Üniversitesi Ziraat Fak. Yayınları: 1021, Ders Kitabi: 295, Ankara. (in Turkish)

Erdoğdu Y. (2012). The effect of different doses of nitrogen on yield, yield charecteristics and essential oil content of coriander (Coriandrum sativum L.). Namık Kemal University Graduate School of Natural and Applied Sciences Department of Field Crops, Master of Thesis, $68 \mathrm{~s}$.

Ghasemi Pirbalouti, A., Salehi, S., Craker, L. (2017). Effect of drying methods on qualitative and quantitative properties of essential oil from the aerial parts of coriander. J. Med. Aromat. Plant Sci 4:3540.

Gökduman, G.A., Telci, İ. (2018). Determination of yield and quality characteristics of some coriander (Coriandrum sativum L.) genotypes in Isparta conditions. Süleyman Demirel Univ. J. Nat. Appl. Sci. 22:1165-1168.

Gücük, F. (2014). Determination of agronomic and quality properties of coriander (Coriandrum sativum L.) varieties and hats sowed in winter and spring periods under Tokat Kazova conditions. Gaziosmanpaşa University Graduate School of Natural and Applied Sciences 


\section{Effects of Zinc Application on Some Important Yield and Quality Characteristics of Coriander (Coriandrum sativum L.)}

Department of Field Crops, Master of Thesis, Tokat, $57 \mathrm{~s}$.

Kan, Y. (2007). The effect of organic and inorganic fertilizer on yield and essential oil of coriander (Coriandrum sativum L.) growing in Konya ecological conditions. Univ. Selcuk J. Fac. Agric. 21:36-42.

Katar, D. (2015). The effect of different sowing densities on yield and yield components of Coriander (Coriandrum sativum) cultivars under Ankara/Turkey ecological conditions. Biol Divers. Conserv. 8:173180.

Kaya, N., Y1lmaz, G., Telci, İ. (2000). Agronomic and technological properties of coriander (Coriandrum sativum L.) populations planted on different dates. Turkish J. Agric. For. 24:355-364.

Keskin, S. (2015). Agricultural and technological properties of some important culture species within the family Umbelliferae in Isparta ecological conditions. Süleyman Demirel University Graduate School of Applied and Natural Sciences Department of Field Crops, Master of Thesis, Isparta, $110 \mathrm{~s}$.

Khodadadi, M., Dehghani. H., Jalali Javaran, M., Christopher. J. T. (2016). Fruit yield, fatty and essential oils content genetics in coriander. Ind. Crop. Prod. 94:72-81.

Kızıl, S., İpek, A. (2004). The Effects of different row spacing on yield, yield components and essential oil content of some coriander (Coriandrum sativum L.) lines. J. Agric. Sci. 10:237-244.

Mandal, S., Mandal, M. (2015). Coriander (Coriandrum sativum L.) essential oil: Chemistry and biological activity. Asian Pac. J. Trop. Biomed. 5:421-428.

Maret, W. (2013). Zinc biochemistry: From a single zinc enzyme to a key element of life. Advances in Nutrition: An Int. Rev. J. 4:82-91.

Msaada, K., Hosni, K., Ben Taarit, M., Chahed, T., Kchouk, M.E., Marzouk, B. (2007). Changes on essential oil composition of coriander (Coriandrum sativum L.) fruits during three stages of maturity. Food Chem. 102:1131-1134.
Özel, A., Güler, İ., Erden, K. (2010). Effect of different sowing time on essential oils components of coriander (Coriandrum sativum L.). Harran J. Agric. Food Sci. 14:55-62.

Deshpande, P., Dapkekar, A., Oak, M. D., Paknikar, K. M., Rajwade, J. M. (2017). Zinc complexed chitosan/TPP nanoparticles: a promising micronutrient nanocarrier suited for foliar application. Carbohydr. Polym. 165:394-401.

Ramadan, M. F., Mörsel, J. T. (2002). Oil composition of coriander (Coriandrum sativum L.) fruit-seeds. Eur. Food Res.Technol. 215:204-209.

Sriti, J., Neffati, M., Msaada, K., Thierry, T., Brahim, M. (2012). Biochemical characterization of coriander cakes obtained by extrusion. J. Chem. 13: 1-6.

Tunçtürk, M. (2006). The effect of different seed rates on the yield, yield components and essential oil rate of coriander (Coriandrum sativum L.). Univ. Selcuk J. Fac. Agric. 20:58-62.

Tunçtürk, R. (2011). Effects of Different Row Spacings on the Yield and Quality in Coriander (Coriandrum sativum L.) Cultivars. Yuzuncu Yll Univ. J. Agric. Sci. 21:89-97.

Ulutaş Deniz, E., Yeğenoğlu, S., Sözen Şahne, B., Gençler Özkan, A. M. (2018). Kişniş (Coriandrum sativum L.) üzerine bir derleme. Marmara Pharm. J. 22:15-28. (in Turkish)

Zoubiri, S., Baaliouamer, A. (2010). Essential oil composition of Coriandrum sativum seed cultivated in Algeria as food grains protectant. Food Chem. 122:1226-1228. 